\title{
Pengaruh Persepsi Manfaat, Persepsi Kemudahan Penggunaan, dan Tingkat Kepercayaan Pada Minat Menggunakan Uang Elektronik
}

\author{
Andhika Bayu Pratama ${ }^{1}$ \\ I Dewa Gede Dharma Suputra² \\ ${ }^{1,2}$ Fakultas Ekonomi dan Bisnis Universitas Udayana (Unud), Bali, Indonesia \\ e-mail: andhikabayu_pratama@yahoo.co.id
}

\begin{abstract}
ABSTRAK
Penelitian ini menggunakan metode survei yang dilakukan dengan menyebarkan kuesioner. Populasi dalam penelitian ini adalah seluruh mahasiswa reguler sore angkatan 2015 yang berjumlah 493 orang. Sampel dalam penelitian ini ditentukan menggunakan teknik nonprobability sampling dengan pendekatan insidental sampling, untuk memperoleh jumlah sampel minimum digunakan rumus Slovin. Berdasarkan hasil perhitungan didapatkan bahwa sampel berjumlah minimal 83 orang. Penelitian ini menggunakan teknik analisis regresi linier berganda. Berdasarkan hasil analisis ditemukan bahwa persepsi manfaat, persepsi kemudahan penggunaan, dan tingkat kepercayaan berpengaruh positif dan signifikan pada minat mahasiswa reguler sore angkatan 2015 Fakultas Ekonomi dan Bisnis Universitas Udayana untuk menggunakan uang elektronik.

Kata Kunci: TAM, persepsi manfaat, persepsi kemudahan penggungaan, tingkat kepercayaan, minat, uang elektronik
\end{abstract}

\begin{abstract}
This study uses a survey by distributing questionnaires. The population in this study were all students of the 2015 afternoon class which numbered 493 people. The sample in this study was determined using a nonprobability sampling technique with an incidental sampling approach. Based on the calculation using Slovin formula, the sample amounted to at least 83 people. This study uses multiple linear regression analysis techniques. Based on the results of the analysis it was found that percieved usefulness, percieved ease of use, and trust had a positive and significant effect on the interest of regular 2015 afternoon students of the Faculty of Economics and Business, Udayana University to use e-money.

Keywords: TAM, perceived usefulness, perceived ease of use, trust, interest, e-money
\end{abstract}

\section{PENDAHULUAN}

Perkembangan teknologi informasi dan komunikasi yang semakin maju telah membawa perubahan yang besar terhadap kehidupan kita. Untuk mengikuti perkembangan teknologi tersebut berbagai kegiatan bisnis mulai mengubah dirinya menjadi perusahaan global, tak terkecuali perbankan. Bank-bank saat ini melakukan berbagai inovasi melalui teknologi modern untuk memberikan pelayanan terbaik. Meningkatnya mobilitas masyarakat akhir-akhir ini menjadikan 
penyedia layanan masyarakat seperti perbankan, harus memutar otak untuk melakukan inovasi dalam melayani semua nasabahnya. Salah satu inovasi yang dikembangkan perbankan adalah dalam hal pembayaran. Perubahan alat pembayaran berkembang sangat pesat mengikuti perkembangan ilmu dan teknologi serta kebutuhan manusia. Saat ini masyarakat telah menyadari akan pentingnya alat transaksi yang tidak bersifat fisik, baik kertas maupun logam, yaitu dengan menggunakan uang elektronik (Adiyanti, 2015).

Uang elektronik merupakan alat pembayaran yang memenuhi unsur-unsur seperti diterbitkan atas dasar nilai uang yang disetor terlebih dahulu oleh pemegang kepada penerbit, nilai uang disimpan secara elektronik dalam suatu media seperti server atau chip, digunakan sebagai alat pembayaran kepada pedagang yang bukan merupakan penerbit uang elektronik tersebut, dan nilai uang elektronik yang sudah disetor oleh pemegang dan dikelola oleh penerbit bukan merupakan simpanan sebagaimana dimaksud dalam undang-undang yang mengatur mengenai perbankan (Bank Indonesia dalam Zulqarnain, 2017). Munculnya uang elektronik dilatar belakangi oleh Peraturan Bank Indonesia Nomor 11/12/PBI/2009 sebagai salah satu pendukung agenda Bank Indonesia untuk menciptakan less cash society di Republik Indonesia. Uang elektronik sendiri bertujuan untuk memudahkan manusia dalam melakukan segala macam transaksi ekonomi di kehidupannya terutama untuk transaksi berskala mikro. Selain tujuan tersebut Bank Indonesia juga dapat menghemat biaya operasional untuk memproduksi uang, baik uang kertas maupun uang logam. Bank Indonesia setidaknya menganggarkan Rp 3,5 triliun untuk pencetakan uang setiap tahun. 
Penggunaan alat pembayaran non-tunai juga dapat mencegah uang rusak atau basah (Adhinagari, 2018). Penerbit atau penyedia dari uang elektronik pun beragam seperti $e$-money yang merupakan produk dari Bank Mandiri, Brizzi yang merupakan produk dari BRI, Tapcash yang merupakan produk dari BNI, Flazz yang merupakan produk dari BCA, Go-pay yang merupakan produk dari Go-Jek, Dana, OVO, dll.

Penggunaan uang elektronik di Bali hingga saat ini masih belum merata. Transaksi menggunakan uang elektronik di Bali masih tergolong terbatas, karena tidak semua pedagang dapat menerima transaksi dengan menggunakan uang elektronik baik yang berbasis kartu maupun software. Berbagai upaya telah dilakukan pemerintah dan penyedia layanan untuk meningkatkan penggunaan uang elektronik di Bali, seperti diwajibkannya pembayaran masuk gerbang Jalan Tol Bali Mandara menggunakan uang elektronik, pembayaran parkir di Bandar Udara I Gusti Ngurah Rai, serta transaksi di berbagai pusat perbelanjaan. Penggunaannya pada lingkungan kampus di Bali terutama pada Fakultas Ekonomi dan Bisnis Universitas Udayana sendiri masih tergolong jarang. Hal tersebut dikarenakan kurangnya kerja sama antar pihak kampus dan bank untuk menciptakan less cash society di dalam lingkungan kampus, sehingga pedagang yang berada didalam lingkungan kampus belum dapat menerima dan memberikan layanan transaksi pembayaran melalui uang elektronik. Selain itu, menurut Utami (2017) mahasiswa lebih suka menggunakan uang tunai sebagai alat pembayaran karena mahasiswa telah terbiasa menggunakan uang tunai yang mana menurut mereka lebih praktis dibandingkan uang elektronik. 
Perkembangan teknologi informasi akan selalu menimbulkan pro dan kontra, untuk itu dilakukan berbagai penelitian untuk menciptakan model yang dapat mengukur serta menganalisis faktor-faktor yang memengaruhi penerimaan teknologi informasi (TI). Salah satu model yang banyak digunakan yaitu Technology Acceptance Model (TAM). TAM diperkenalkan oleh Davis et al. (1989) model ini berasumsi bahwa variable perceived usefulness dan perceived ease of use menjadi dasar yang mempengaruhi perilaku pengguna dan tingkat penerimaan teknologi informasi.

Manfaat serta kemudahan yang ditawarkan uang elektronik dapat mempengaruhi peningkatan penggunanya. Ketika sebuah produk memiliki manfaat dan kemudahan ketika digunakan dalam kehidupan sehari-hari, maka kemungkinan produk tersebut akan digunakan oleh masyarakat luas. Begitu pula dengan uang elektronik yang dirasa sangat membantu untuk kepentingan transaksi perekonomiannya, bukan tidak mungkin masyarakat akan berminat untuk menggunakan uang elektronik.

Selain itu, faktor tingkat kepercayaan terhadap produk juga akan berpengaruh dalam minat menggunakan uang elektronik. Menurut Jogiyanto (2007:397) kepercayaan adalah penilaian seorang individu setelah memperoleh, memproses, dan mensintesis informasi dan menghasilkan berbagai penilaian dan anggapan. Konsep tingkat kepercayaan disini adalah kehandalan pihak produsen atau penyedia layanan uang elektronik dalam menjamin keamanan dan kerahasiaan instrumen yang digunakan konsumen untuk membuat penggunanya percaya. 
Hasil penelitian Purwiati (2013) menunjukkan bahwa beberapa faktor yang dapat mempengaruhi adopsi uang elektronik adalah keamanan dan kerahasiaan, manfaat kegunaan, kemudahan penggunaan, kesenangan, kepercayaan, kecukupan informasi, dan sikap masyarakat atas penggunaan uang elektronik. Sementara Sanofata (2014) menyatakan bahwa faktor-faktor yang mempengaruhi intensi punggunaan uang elektronik, yaitu perceived ease of use, perceived usefulness, information on e-money, security and privacy, dan accessibility. Adhinagari (2018) dalam penelitiannya menyatakan bahwa faktor persepsi manfaat, kemudahan penggunaan, dan kepercayaan berpengaruh positif signifikan terhadap persepsi penggunaan uang elektronik, sedangkan faktor resiko berpengaruh negatif signifikan terhadap persepsi penggunaan uang elektronik. Listianti (2018) dalam penelitiannya menyatakan bahwa persepsi manfaat, persepsi kemudahan penggunaan, dan kepercayaan berpengaruh secara positif dan signifikan terhadap penggunaan uang elektronik. Hasil penelitian terdahulu menunjukkan bahwa banyak faktor-faktor yang memengaruhi minat seseorang menggunakan layanan uang elektronik. Penelitian ini menggunakan tiga faktor yang digunakan sebagai landasan, yaitu persepsi manfaat, persepsi kemudahan penggunaan, dan tingkat kepercayaan.

TAM yang dikemukakan oleh Davis et al. (1989) merupakan perluasan dari Theory of Reasoned Action (TRA) dan Theory of Planned Behavior (TPB) oleh Ajzen dan Fishbein (1980). TAM mengajukan dua konstruk teoritis, yaitu persepsi manfaat (percieved usefulness) dan persepsi kemudahan penggunaan (percieved ease of use) sebagai penentu fundamental penerimaan pengguna dari 
suatu sistem informasi. Persepsi manfaat dan persepsi kemudahan keduanya memiliki pengaruh ke minat berperilaku (behavior intention). Minat menggunakan teknologi akan muncul jika sistem teknologi dirasa bermanfaat dan mudah digunakan.

Tujuan TAM adalah untuk menjelaskan faktor-faktor utama dari perilaku pengguna terhadap penerimaan pengguna teknologi. Secara lebih terinci menjelaskan tentang penerimaan teknologi informasi dengan dimensi-dimensi tertentu yang dapat mempengaruhi diterimanya (Davis et al., 1989). TAM dirancang untuk mencapai tujuan tersebut dengan cara mengidentifikasi beberapa variabel dasar yang disarankan pada penelitian sebelumnya yang setuju dengan faktor-faktor yang mempengaruhi secara kognitif dan afektif pada penerimaan teknologi dan menggunakan TRA sebagai dasar teorikal untuk menentukan model hubungan variable penelitian.

Konstruk pertama adalah perceived usefulness, didefinisikan sebagai sejauh mana seorang percaya bahwa menggunakan suatu teknologi akan meningkatkan kinerjanya. Konstruk kedua adalah perceived ease of use, didefinisikan sebagai sejauh mana seorang percaya bahwa menggunakan suatu teknologi akan bebas dari usaha. Perceived usefulness dan perceived ease of use memengaruhi attitude toward using seseorang terhadap penggunaan teknologi. Peningkatan pada perceived ease of use secara instrumental memengaruhi kenaikan dari perceived usefulness karena sebuah sistem yang mudah digunakan tidak membutuhkan waktu yang lama untuk dipelajari sehingga seseorang memiliki kesempatan untuk mengerjakan sesuatu yang lain sehingga berkaitan 
dengan efektifitas kinerja (Davis, 1989). Konstruk ketiga yaitu attitude toward using, didefinisikan sebagai evaluasi dari pemakai tentang ketertarikannya dalam menggunakan teknologi. Konstruk keempat yaitu behavioral intention to use, didefinisikan sebagai minat seseorang untuk melakukan perilaku tertentu. Konstruk yang terakhir yaitu actual system usage, diukur dengan jumlah waktu yang digunakan untuk berinteraksi dengan teknologi dan frekuensi penggunaan teknologi tersebut.

Menurut Jogiyanto (2007:114) yang dimaksud dengan manfaat yang dirasakan atau Perceived Usefulness adalah sejauh mana seseorang percaya bahwa menggunakan suatu teknologi tertentu akan meningkatkan kinerja pekerjaannya. Sedangkan Dalcher dan Shine (2003) mendefinisikan persepsi manfaat sebagai konstruk kepercayaan seseorang bahwa penggunaan sebuah teknologi tertentu akan mampu meningkatkan kinerja mereka. Maka, dapat disimpulkan dalam penelitian ini yang dimaksud dengan persepsi manfaat adalah pandangan subjektif nasabah atas manfaat yang diperoleh dengan menggunakan layanan uang elektronik.

Dari definisi di atas, diketahui bahwa manfaat yang dirasakan merupakan suatu kepercayaan tentang proses pengambilan keputusan. Jika seseorang merasa percaya bahwa suatu teknologi berguna maka dia akan menggunakannya, sedangkan jika menurutnya teknologi tersebut kurang berguna maka dia tidak akan menggunakannya. Sikap positif untuk menggunakan uang elektronik timbul karena nasabah merasa yakin bahwa uang elektronik dapat meningkatkan kinerja, produktivitas, dan keefektifan kinerja bagi nasabah. 
Menurut Jogiyanto (2007:114), penelitian-penelitian sebelumnya yang dilakukan oleh Davis et al. (1989), Chau (1996), Igbaria et al. (1997), dan Sun (2003) menunjukkan bahwa konstruk persepsi manfaat mempengaruhi secara positif dan signifikan terhadap penggunaan sistem informasi. Penelitian-penelitian sebelumnya juga menunjukkan bahwa persepsi manfaat merupakan konstruk yang paling banyak signifikan dan penting yang mempengaruhi sikap, minat, dan perilaku di dalam menggunakan teknologi dibandingkan dengan konstruk yang lainnya.

Menurut Jogiyanto (2007) minat merupakan suatu fungsi dari dua penentu dasar, yaitu: penentu yang berhubungan dengan faktor pribadi. Penentu ini adalah sikap terhadap perilaku individual. Sikap ini adalah evaluasi kepercayaan atau perasaan positif atau negatif jika harus melakukan perilaku tertentu dan penentu yang berhubungan dengan pengaruh sosial. Penentu ini adalah norma subjektif. Norma subjektif yang dimaksud disini yaitu berhubungan dengan persepsi atau pandangan seseorang terhadap tekanan sosial yang akan memengaruhi minat untuk melakukan sesuatu atau tidak melakukan perilaku yang sedang dipertimbangkan.

Menurut Jogiyanto (2007:115), pengertian Perceived Ease of Use atau persepsi kemudahan penggunaan didefinisikan sebagai sejauh mana seseorang percaya bahwa menggunakan suatu sistem teknologi tertentu akan bebas dari suatu usaha. Davis et al. (1989) mendefinisikan persepsi kemudahan penggunaan merupakan tingkatan dimana seseorang percaya bahwa teknologi mudah untuk dipahami. Berdasarkan definisinya, diketahui bahwa konstruk kemudahan 
penggunaan ini juga merupakan suatu kepercayaan tentang proses pengambilan keputusan. Jika seseorang merasa percaya bahwa sistem informasi mudah digunakan, maka ia akan menggunakannya. Dan sebaliknya, jika seseorang merasa percaya bahwa sistem informasi ini tidak mudah digunakan, maka ia tidak akan menggunakannya.

Penelitian-penelitian sebelumnya juga menunjukkan bahwa konstruk kemudahan penggunaan mempengaruhi persepsi manfaat, sikap, minat, dan penggunaan sesungguhnya. Dalam penelitian ini yang dimaksudkan dengan kemudahan penggunaan adalah tingkat kemudahan dalam penggunaan layanan uang elektronik.

Menurut Jogiyanto (2007:397), kepercayaan mewakili struktur-struktur kognitif yang dikembangkan oleh individual setelah mengumpulkan, memproses, dan mensintesis informasi, dan memasukkan penilaian-penilaian individual dari bermacam-macam hasil (outcomes) yang berkaitan. Sedangkan menurut Ba dan Pavlou (2002), kepercayaan didefinisikan sebagai penilaian hubungan seseorang dengan orang lain yang akan melakukan transaksi tertentu sesuai dengan harapan dalam sebuah lingkungan yang penuh ketidakpastian. Morgan dan Hunt dalam Wanandi (2014) mendefinisikan bahwa kepercayaan akan terjadi apabila seseorang memiliki kepercayaan diri dalam sebuah pertukaran dengan mitra yang memiliki integritas dan dapat dipercaya. Kepercayaan adalah kemauan untuk membuat dirinya peka pada tindakan yang diambil leh orang yang dipercayainya berdasarkan pada rasa kepercayaan dan tanggung jawab (Gefen, 2002). Berdasarkan beberapa definisi tersebut, dapat disimpulkan bahwa tingkat 
kepercayaan adalah penilaian oleh seorang individu setelah memperoleh, memproses, dan mensintesis informasi dan menghasilkan berbagai penilaian dan anggapan pada situasi yang tak pasti.

Lewis et al. (2003) dalam Jogiyanto (2007:398) berpendapat bahwa kepercayaan-kepercayaan individual terhadap teknologi informasi dibentuk dari tiga faktor yaitu faktor-faktor institusional, sosial, dan individual. Peran faktor institusional dalam mempengaruhi perilaku individual terhadap teknologi informasi telah menjadi subyek yang menarik di penelitian sistem informasi. Lewis et al. (2003) menunjukkan faktor-faktor instituasional yang berpengaruh adalah komitmen dan dukungan manajemen yang juga sudah digunakan di beberapa penelitian. Sedangkan konsepsualisasi mengenai pengaruh sosial berdasarkan konsep dari Fulk (1993) beragumentasi dan secara empiris menunjukkan bahwa seberapa penting orang-orang lain memandang penggunaan teknologi sebagai sesuatu yang bermanfaat mempunyai suatu pengaruh yang positif pada persepsi seseorang mengenai manfaatnya. Lebih lanjut, pengaruh yang penting terhadap kognitif individual mengenai teknologi informasi yang sudah dijelaskan dan ditunjukkan oleh hasil-hasil dari penelitian sebelumnya. Dua faktor individual yang paling banyak ditemukan di penelitian-penelitian sebelumnya mempengaruhi kepercayaan-kepercayaan individual adalah computer self efficacy dan personal innovativeness. Dalam penelitian ini kerpercayaan berkenaan dengan keyakinan atas kemampuan dan integritas dari layanan uang elektronik. 
Minat adalah keinginan untuk berperilaku. Davis et al. (1989) mendefinisikan minat berperilaku atau menggunakan sebagai tingkat seberapa kuat keinginan atau dorongan seseorang untuk melakukan perilaku tertentu. Ketika seseorang melihat bahwa sesuatu akan bermanfaat, maka ia akan menjadi berminat sehinggga hal tersebut akan mendatangkan dorongan untuk mencapai kepuasan tersebut.

Minat merupakan suatu keadaan dalam diri seseorang pada dimensi kemungkinan subjektif yang meliputi hubungan antara orang itu sendiri dengan beberapa tindakan (Ajzen dalam Wibowo, 2015). Minat adalah keinginan yang didorong oleh suatu keinginan setelah melihat, mengamati dan membandingkan serta mempertimbangkan dengan kebutuhan yang diinginkannya. Minat konsumen terhadap produk yang inovatif bisa dianalisis dengan melihat ke sisi internal dan sisi eksternal produk. Sisi internal, di mana itu tergantung pada pengetahuan, kapasitas, sumber daya dan teknologi yang digunakan di perusahaan sementara sisi eksternal adalah kebutuhan konsumen dan harapan pemilik terhadap produk perusahaan (Seng dan Ping, 2016).

Uang elektronik atau e-money berdasarkan publikasi yang diterbitkan oleh Bank for International Settlement (BIS) didefinisikan sebagai suatu produk stored-value atau prepaid dimana sejumlah nilai uang disimpan dalam suatu media elektronis yang dimiliki seseorang (Hidayati et al., 2006). Dirk (2017) mengemukakan bahwa uang elektronik menjadi bagian terbesar dari semua uang yang dikeluarkan saat ini. Uang elektronik adalah versi uang fisik yang tidak dicetak tetapi di transfer secara elektronik. Menurut Chiu dan Wong (2014) uang 
elektronik adalah kartu prabayar multi-tujuan, nilai kartu tersimpan untuk transportasi umum yang juga diterima pada tempat penjualan. Uang elektronik diatur dalam PBI Nomor 16/8/PBI/2014 tentang perubahan atas PBI Nomor 11/12/PBI/2009 tentang uang elektronik.

Beberapa manfaat atau kelebihan dari penggunaan uang elektronik dibandingkan dengan uang tunai maupun alat pembayaran non-tunai lainnya, antara lain (Hidayati et al., 2006): Lebih cepat dan nyaman dibandingkan dengan uang tunai, khususnya untuk transaksi yang bernilai kecil (micro payment), disebabkan pengguna tidak perlu menyediakan sejumlah uang pas untuk suatu transaksi atau harus menyimpan uang kembalian. Selain itu, kesalahan dalam menghitung uang kembalian dari suatu transaksi tidak terjadi apabila menggunakan uang elektronik.

Waktu yang diperlukan untuk menyelesaikan suatu transaksi dengan uang elektronik dapat dilakukan jauh lebih singkat dibandingkan transaksi dengan kartu kredit atau kartu debit, karena tidak harus memerlukan proses otorisasi on-line, tanda tangan maupun PIN. Electronic value dapat diisi ulang kedalam kartu uang elektronik melalui berbagai sarana yang disediakan.

Uang elektronik dalam bentuk card-based product sering juga disebut sebagai electronic purses. Card-based product pada prinsipnya dimaksudkan untuk pembayaran yang bersifat langsung (face to face). Jenis produk ini menggunakan media kartu dengan teknologi integrated circuit (IC) atau dikenal dengan "IC Card" yang mengandung microprocessor chip. 
Jenis uang elektronik ini sering disebut juga digital cash. Produk uang elektronik yang masuk dalam kelompok ini pada prinsipnya merupakan suatu aplikasi (software) yang kemudian di-install ke dalam suatu Personal Computer (PC) atau pun smartphone. Produk ini dikembangkan untuk melakukan transaksi melalui suatu jaringan komputer.

Manfaat yang dirasakan atau Perceived Usefulness menurut Jogiyanto (2007:114) adalah sejauh mana seseorang percaya bahwa menggunakan suatu teknologi tertentu akan meningkatkan kinerja pekerjaannya. Jika seseorang merasa percaya bahwa suatu teknologi berguna maka dia akan menggunakannya, sedangkan jika menurutnya teknologi tersebut kurang berguna maka dia tidak akan menggunakannya.

Beberapa penelitian sebelumnya yang dilakukan oleh Davis et al. (1989), Purwiati (2013), Sanofata (2014), Adiyanti (2015), dan Adhinagari (2018) menunjukkan bahwa konstruk persepsi manfaat mempengaruhi secara positif dan signifikan terhadap penggunaan sistem informasi. Berdasarkan penjelasan di atas dan hasil penelitian sebelumnya, maka hipotesis dalam penelitian ini adalah:

$\mathrm{H}_{1}$ : Persepsi manfaat berpengaruh positif terhadap minat menggunakan uang elektronik

Perceived Ease of Use atau persepsi kemudahan penggunaan didefinisikan sebagai sejauh mana seseorang percaya bahwa menggunakan suatu sistem teknologi tertentu akan bebas dari suatu usaha (Jogiyanto, 2007:115). Jika seseorang merasa percaya bahwa sistem informasi mudah digunakan, maka ia akan menggunakannya. 
Penelitian sebelumnya yang dilakukan oleh Davis et al. (1989), Purwiati (2013), Sanofata (2014), Adiyanti (2015), dan Adhinagari (2018) menunjukkan bahwa konstruk persepsi kemudahan penggunaan mempengaruhi secara positif dan signifikan terhadap penggunaan sistem informasi. Berdasarkan penjelasan di atas dan hasil penelitian sebelumnya, maka hipotesis dalam penelitian ini adalah:

$\mathrm{H}_{2}$ : Persepsi kemudahan penggunaan berpengaruh positif terhadap minat menggunakan uang elektronik

Menurut Jogiyanto (2007: 397), kepercayaan mewakili struktur-struktur kognitif yang dikembangkan oleh individual setelah mengumpulkan, memproses, dan mensintesis informasi, dan memasukkan penilaian-penilaian individual dari bermacam-macam hasil (outcomes) yang berkaitan. Sedangkan menurut Ba dan Pavlou (2002), kepercayaan didefinisikan sebagai penilaian hubungan seseorang dengan orang lain yang akan melakukan transaksi tertentu sesuai dengan harapan dalam sebuah lingkungan yang penuh ketidakpastian.

Penelitian sebelumnya yang dilakukan oleh Wibowo (2015) menyatakan bahwa tingkat kepercayaan berpengaruh terhadap minat menggunakan prepaid card (kartu prabayar). Penelitian yang dilakukan oleh Adiyanti (2015) dan Listianti (2018) juga menyatakan bahwa tingkat kepercayaan yang tinggi akan mempengaruhi minat seseorang dalam menggunakan produk baru tersebut. Berdasarkan penjelasan di atas dan hasil penelitian sebelumnya, maka hipotesis dalam penelitian ini adalah:

$\mathrm{H}_{3}$ : Tingkat kepercayaan berpengaruh positif terhadap minat menggunakan uang elektronik 
Kerangka konseptual pada penelitian ini menunjukkan hubungan antara variabel dependen dengan variabel-variabel independen. Dalam penelitian ini, minat menggunakan uang elektronik (Y) merupakan variable dependen, sedangkan persepsi manfaat $\left(\mathrm{X}_{1}\right)$, persepsi kemudahan penggunaan $\left(\mathrm{X}_{2}\right)$, dan tingkat kepercayaan $\left(\mathrm{X}_{3}\right)$ merupakan variabel-variabel independen dalam penelitian ini.

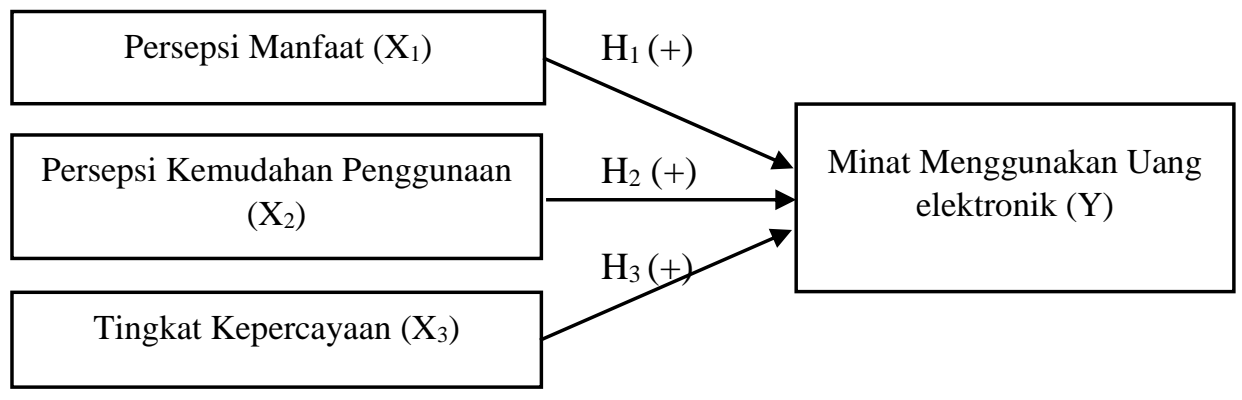

Sumber: Data diolah, 2018

\section{Gambar 1. Kerangka Konseptual}

\section{METODE PENELITIAN}

Lokasi dari penelitian ini bertempat di Fakultas Ekonomi dan Bisnis Universitas Udayana yakni program reguler sore. Adapun objek dalam penelitian ini adalah faktor-faktor yang memengaruhi minat menggunakan uang elektronik.

Populasi dalam penelitian ini adalah semua mahasiswa program non reguler angkatan 2015 di Fakultas Ekonomi dan Bisnis Universitas Udayana. Metode penentuan sampel yang dipilih adalah nonprobability sampling dengan menggunakan insidental sampling. Insidental sampling adalah suatu teknik pengambilan sampel berdasarkan kebetulan, yaitu siapa saja yang kebetulan ditemui peneliti dapat digunakan sebagai sampel apabila orang yang kebetulan 
ditemui cocok sebagai sumber data dengan kriteria utamanya pernah menggunakan uang elektronik.

Perhitungan analisa yang digunakan pada penelitian ini yaitu regresi linear berganda dengan bantuan komputer program Statistical Produst and Service Solutions (SPSS). Analisis regresi linier berganda adalah pengujian yang dilakukan untuk mengetahui ketergantungan satu variabel terikat pada satu variabel bebas dengan atau tanpa variabel moderasi. Analisis regresi linear berganda dilakukan untuk mengetahui pengaruh persepsi manfaat, persepsi kemudahan penggunaan, dan tingkat kepercayaan terhadap minat menggunakan uang elektronik yang akan diuji dengan tingkat signifikansi $\alpha=5 \%$. Rumus dari model regresi linier berganda adalah:

$Y=\alpha+\beta_{1} X_{1}+\beta_{2} X_{2}+\beta_{3} X_{3}+e$

Keterangan:

$\mathrm{Y}=$ Minat menggunakan uang elektronik

$\alpha=$ Nilai konstanta

$\mathrm{X}_{1}=$ Persepsi Manfaat

$\mathrm{X}_{2}=$ Persepsi Kemudahan penggunaan

$\mathrm{X}_{3}=$ Tingkat kepercayaan

$\beta_{1}=$ Koefisien regresi dari Persepsi Manfaat $\left(X_{1}\right)$

$\beta_{2}=$ Koefisien regresi dari Persepsi Kemudahan penggunaan $\left(X_{2}\right)$

$\beta_{3}=$ Koefisien regresi dari Tingkat Kepercayaan $\left(\mathrm{X}_{3}\right)$

$e=$ error (tingkat kesalahan pengganggu)

Berdasarkan hasil analisis yang dilakukan dapat diamati mengenai koefisien determinasi $\left(\mathrm{R}^{2}\right)$, uji kelayakan model (uji F), dan uji hipotesis (uji t). 


\section{HASIL DAN PEMBAHASAN}

Karakteristik responden yang diteliti meliputi jenis kelamin, program studi dan pengeluaran responden yang berpartisipasi dalam pengisian kuesioner ini.

Tabel 1.

Karakteristik Responden Berdasarkan Jenis Kelamin

\begin{tabular}{lccc}
\hline & Jenis Kelamin & Jumlah (orang) & $\%$ \\
\hline Laki-laki & 44 & 53,01 \\
Perempuan & 39 & 46,99 \\
Total & 83 & 100 \\
\hline
\end{tabular}

Sumber: Data diolah, 2018

Berdasarkan Tabel 1 jumlah responden yang didapat adalah laki-laki berjumlah 44 orang dan perempuan 39 orang perbandingan jumlah laki-laki dan perempuan hampir setara.

Tabel 2.

Karakteristik Responden Berdasarkan Program Studi

\begin{tabular}{|c|c|c|}
\hline Program Studi & Jumlah(orang) & $\%$ \\
\hline Akuntansi & 55 & 66,27 \\
\hline Manajemen & 17 & 20,48 \\
\hline Ekonomi Pembangunan & 11 & 13,25 \\
\hline Total & 83 & 100 \\
\hline
\end{tabular}

Sumber: Data diolah, 2018

Berdasarkan Tabel 2 didapatkan bahwa jurusan responden paling banyak didominasi oleh mahasiswa jurusan akuntansi yaitu sebanyak 55 orang, sedangkan jurusan ekonomi pembangunan memiliki jumlah yang paling sedikit yaitu berjumlah 11 orang.

Tabel 3.

Karakteristik Responden Berdasarkan Pengeluaran

\begin{tabular}{ccccccccc}
\hline \multirow{2}{*}{ Pengeluaran/bulan } & \multicolumn{9}{c}{ Jurusan \& Jenis Kelamin } & \multicolumn{2}{c}{ Total } \\
& \multicolumn{2}{c}{ AK } & \multicolumn{2}{c}{ MJ } & \multicolumn{2}{c}{ EP } & \multicolumn{2}{c}{ L } \\
& L & P & L & P & L & P & \\
\hline$<500.000$ & 7 & 6 & 0 & 0 & 2 & 2 & 17 \\
$500.000-2.000 .000$ & 22 & 18 & 3 & 3 & 6 & 4 & 56 \\
$2.000 .000-3.000 .000$ & 1 & 2 & 2 & 2 & 0 & 0 & 7 \\
$3.000 .000-5.000 .000$ & 0 & 0 & 0 & 0 & 2 & 1 & 3 \\
$>5.000 .000$ & 0 & 0 & 0 & 0 & 0 & 0 & 0 \\
Total & 30 & 26 & 5 & 5 & 10 & 7 & 83 \\
\hline
\end{tabular}

Sumber: Data diolah, 2018 
Berdasarkan Tabel 3 dapat dilihat bahwa mahasiswa reguler sore dengan pengeluaran sebesar Rp. 500.000 - Rp. 2.000.000 mendominasi sebanyak 56 orang yang terdiri dari mahasiswa jurusan akuntansi sebanyak 40 orang, mahasiswa jurusan manajemen sebanyak 6 orang, dan mahasiswa jurusan ekonomi pembangunan sebanyak 10 orang. Pengeluaran dengan jumlah Rp. 5.000.000 memiliki jumlah yang paling sedikit yaitu 0 .

Statistik Deskriptif dalam penelitian ini disajikan untuk memberikan informasi tentang karakteristik variabel penelitian, antara lain nilai minimum, maksimum, mean dan standar deviasi. Untuk mengukur nilai sentral dari suatu distribusi data umumnya digunakan pengukuran rata-rata (mean), sedangkan untuk mengukur perbedaan nilai data yag diteliti dengan nilai rata-ratanya digunakan standar deviasi. Statistik deskriptif dalam penelitian ini dapat dilihat dalam Tabel 4 di bawah ini.

Tabel 4.

Hasil Uji Statistik Deskriptif

\begin{tabular}{cccccc}
\hline Variabel & N & Min. & Max. & Mean & Std. Deviation \\
\hline Persepsi Manfaat & 83 & 6,76 & 19,62 & 15,67 & 3,31249 \\
Persepsi Kemudahan Penggunaan & 83 & 5,23 & 17,09 & 12,41 & 3,44261 \\
Tingkat Kepercayaan & 83 & 8,88 & 21,28 & 15,99 & 3,50097 \\
Minat Menggunakan Uang elektronik & 83 & 4,04 & 14,75 & 11,28 & 2,64519 \\
\hline Sumber: Data diolah, 2018 & & & &
\end{tabular}
Sumber: Data diolah, 2018

Berdasarkan Tabel 4 dijelaskan bahwa nilai dari statistik deskriptif yang meliputi nilai minimum, maksimum, rata-rata dan standar deviasi dengan $\mathrm{N}$ sebanyak 83 responden yang diolah. Nilai minimum variabel persepsi manfaat sebesar 6,76 dan nilai maksimum sebesar 19,62. Nilai rata-rata variabel persepsi manfaat sebesar 15,67 dimana nilai tersebut mendekati nilai maksimal artinya persepsi manfaat yang dimiliki oleh responden cenderung tinggi. Deviasi standar 
variabel persepsi manfaat adalah 3,31249 yang memiliki makna dimana terjadi penyimpangan nilai persepsi manfaat pada nilai rata-ratanya sebesar 3,31249.

Nilai minimum variabel persepsi kemudahan penggunaan sebesar 5,23 dan nilai maksimum sebesar 17,09. Nilai rata-rata variabel persepsi kemudahan penggunaan sebesar 12,41 dimana nilai tersebut mendekati nilai maksimal artinya persepsi kemudahan penggunaan yang dimiliki oleh responden cenderung tinggi. Deviasi standar variabel persepsi kemudahan penggunaan adalah 3,44261 yang memiliki makna dimana terjadi penyimpangan nilai persepsi kemudahan penggunaan pada nilai rata-ratanya sebesar 3,44261.

Nilai minimum variabel tingkat kepercayaan adalah sebesar 8,88 dan nilai maksimum sebesar 21,28. Nilai rata rata variabel tingkat kepercayaan sebesar 15,99 dimana nilai tersebut mendekati nilai maksimal artinya tingkat kepercayaan yang dimiliki oleh responden cenderung tinggi. Deviasi standar variabel tingkat kepercayaan adalah 3,50097 yang memiliki makna dimana terjadi penyimpangan nilai tingkat kepercayaan pada nilai rata-ratanya sebesar 3,50097.

Nilai minimum dari variabel minat menggunakan uang elektronik sebesar 4,04 dan nilai maksimum sebesar 14,75. Nilai rata-rata variabel minat menggunakan uang elektronik sebesar 11,28 dimana nilai tersebut mendekati nilai maksimal artinya minat menggunakan uang elektronik yang dimiliki oleh responden cenderung tinggi. Deviasi standar variabel minat menggunakan uang elektronik adalah 2,64519 yang memiliki makna dimana terjadi penyimpangan nilai minat menggunakan uang elektronik pada nilai rata-ratanya sebesar 2,64519. 
Analisis regresi digunakan untuk mengukur besarnya pengaruh variabel bebas pada variabel terikat dan memprediksi variabel terikat dengan menggunakan variabel bebas. Analisis regresi linier berganda diolah dengan bantuan SPSS. Hasil pengujian disajikan pada Tabel 5 berikut ini:

Tabel 5.

Hasil Analisis Regresi Linier Berganda

\begin{tabular}{|c|c|c|c|c|c|}
\hline \multirow[t]{2}{*}{ Model } & \multicolumn{2}{|c|}{$\begin{array}{c}\text { Unstandarized } \\
\text { Coefficient }\end{array}$} & \multirow{2}{*}{$\begin{array}{c}\text { Standardized } \\
\text { Coefficient } \\
\text { Beta }\end{array}$} & \multirow[t]{2}{*}{$\mathrm{t}$} & \multirow[t]{2}{*}{ Sig. } \\
\hline & $\mathrm{B}$ & Std. Error. & & & \\
\hline Constant & 0,837 & 1,0881 & & 0,775 & 0,441 \\
\hline $\mathrm{X}_{1}$ & 0,210 & 0,074 & 0,263 & 2,817 & 0,006 \\
\hline $\mathrm{X}_{2}$ & 0,254 & 0,079 & 0,330 & 3,227 & 0,002 \\
\hline $\mathrm{X}_{3}$ & 0,250 & 0,006 & 0,331 & 3,809 & 0,000 \\
\hline \multicolumn{6}{|c|}{ Adjusted $\mathrm{R}_{\text {square }}: 0,572$} \\
\hline \multicolumn{6}{|c|}{$F_{\text {hitung }}: 37,570$} \\
\hline \multicolumn{6}{|c|}{ Sig $F_{\text {hitung }}: 0,000$} \\
\hline
\end{tabular}

Berdasarkan Tabel 5 maka disusun persamaan regresi linear berganda sebagai berikut:

$$
\mathrm{Y}=0,837+0,210 \mathrm{X}_{1}+0,254 \mathrm{X}_{2}+0,250 \mathrm{X}_{3}+e
$$

Nilai konstanta $(\alpha)$ sebesar 0,837 memiliki arti jika variabel persepsi manfaat, persepsi kemudahan penggunaan, dan kepercayaan dinyatakan konstan pada angka 0 , maka nilai minat menggunakan uang elektronik sebesar 0,837 .

Koefisien regresi $\beta_{1}$ untuk variabel persepsi manfaat sebesar 0,210 memiliki arti bahwa jika variabel persepsi manfaat meningkat maka akan menyebabkan peningkatan pada minat menggunakan uang elektronik, dengan asumsi variabel bebas lainnya dianggap konstan.

Koefisien regresi $\beta_{2}$ untuk variabel persepsi kemudahan penggunaan sebesar 0,254 memiliki arti bahwa jika variabel persepsi kemudahan penggunaan 
meningkat maka akan menyebabkan peningkatan pada minat menggunakan uang elektronik, dengan asumsi variabel bebas lainnya dianggap konstan.

Koefisien regresi $\beta_{3}$ untuk variabel tingkat kepercayaan sebesar 0,250 memiliki arti bahwa jika variabel tingkat kepercayaan meningkat maka akan menyebabkan peningkatan pada minat menggunakan uang elektronik, dengan asumsi variabel bebas lainnya dianggap konstan.

Koefisien determinasi yang digunakan pada analisis regresi linear berganda adalah nilai Adjusted $\mathrm{R}^{2}$. Hasil analisis menunjukkan bahwa nilai Adjusted $R^{2}$ sebesar 0,572. Ini berarti perubahan yang terjadi pada minat menggunakan uang elektronik dapat dijelaskan oleh persepsi manfaat, persepsi kemudahan penggunaan dan kepercayaan sebesar 57,2\% sedangkan sisanya dijelaskan oleh faktor lain yang tidak diuji dalam penelitian ini.

Tabel 5 menunjukkan bahwa nilai Fhitung yang diperoleh adalah 37,570 dengan signifikansi 0,000. Signifikansi ini jelas lebih kecil dari Alpha $(\alpha=0,05)$ maka model regresi telah memenuhi prasyarat kelayakan model regresi.

Hipotesis pertama menyatakan bahwa persepsi manfaat berpengaruh positif pada minat menggunakan uang elektronik. Pengujian pada hipotesis pertama menunjukkan bahwa nilai koefisien regresi persepsi manfaat sebesar 2,817 dengan nilai signifikansi 0,006 yaitu lebih kecil dari 0,05. Berdasarkan hal tersebut maka hipotesis pertama diterima, artinya persepsi manfaat berpengaruh positif pada minat menggunakan uang elektronik.

Hipotesis kedua menyatakan bahwa persepsi kemudahan penggunaan berpengaruh positif pada minat menggunakan uang elektronik. Pengujian pada 
hipotesis kedua menunjukkan bahwa nilai koefisien regresi persepsi kemudahan penggunaan sebesar 3,227 dengan nilai signifikansi 0,002 yaitu lebih kecil dari 0,05. Berdasarkan hal tersebut maka hipotesis kedua diterima, artinya persepsi kemudahan penggunaan berpengaruh positif pada minat menggunakan uang elektronik.

Hipotesis ketiga menyatakan bahwa tingkat kepercayaan berpengaruh positif pada minat menggunakan uang elektronik. Pengujian pada hipotesis ketiga menunjukkan bahwa nilai koefisien regresi kepercayaan sebesar 3,809 dengan nilai signifikansi 0,000 yaitu lebih kecil dari 0,05. Berdasarkan hal tersebut maka hipotesis ketiga diterima, artinya tingkat kepercayaan berpengaruh positif pada minat menggunakan uang elektronik.

Hasil penelitian ini mendukung hipotesis pertama yang menyatakan persepsi manfaat berpengaruh positif pada minat menggunakan uang elektronik. Hal ini berarti semakin besar persepsi manfaat akan meningkatkan minat menggunakan uang elektronik. Responden yang merasa akan mendapatkan manfaat dengan menggunakan uang elektronik akan berminat untuk menggunakan uang elektronik. Responden merasa dengan menggunakan uang elektronik dalam kegiatan sehari-hari akan meningkatkan produktivitas, membantu kinerja menjadi lebih efisien, dan sangat membantu dalam aktifitas transaksi pembayaran.

Hasil penelitian ini didukung oleh penelitian Davis et al. (1989), Purwiati (2013), Sanofata (2014), Adiyanti (2015), dan Adhinagari (2018) yang menunjukkan bahwa konstruk persepsi manfaat mempengaruhi secara positif dan signifikan pada minat penggunaan teknologi informasi. Hasil penelitian ini sesuai 
dengan konstruk teori TAM, dalam TAM dijelaskan bahwa manfaat suatu teknologi juga mempengaruhi diterimanya sebuah teknologi informasi oleh pengguna.

Hasil penelitian ini mendukung hipotesis kedua yang menyatakan persepsi kemudahan penggunaan berpengaruh positif pada minat menggunakan uang elektronik. Jika responden merasa percaya bahwa sistem informasi mudah digunakan, maka ia akan menggunakannya. Responden juga merasa uang elektronik mudah dipelajari, mudah digunakan, mudah dimengerti, dan mudah untuk menjadi terampil.

Hasil penelitian ini didukung oleh penelitian Davis et al. (1989), Purwiati (2013), Sanofata (2014), Adiyanti (2015), dan Adhinagari (2018) yang menunjukkan bahwa konstruk persepsi kemudahan penggunaan mempengaruhi secara positif dan signifikan pada minat penggunaan teknologi informasi. Hasil penelitian ini sesuai dengan konstruk teori TAM, dalam TAM persepsi kemudahan penggunaan menjadi faktor paling penting yang juga dapat memengaruhi diterimanya suatu teknologi informasi oleh pengguna.

Hasil penelitian ini membuktikan bahwa tingkat kepercayaan berpengaruh positif pada minat menggunakan uang elektronik. Kepercayaan dibutuhkan oleh pengguna teknologi informasi untuk mengurangi kompleksitas sosial dalam menghadapi kemungkinan yang tidak diinginkan. Maka dapat disimpulkan semakin dapat dipercayanya penyedia layanan uang elektronik tersebut maka pengguna akan merasa tenang dalam penggunaannya dikarenakan produk uang 
elektronik tersebut memiliki pelayanan yang baik, bertanggung jawab dan berintegritas tinggi.

Hasil penelitian ini juga didukung oleh Adiyanti (2015), Adhinagari (2018), dan Listianti (2018) yang menunjukkan bahwa tingkat kepercayaan dari pengguna memengaruhi secara positif dan signifikan pada minat penggunaan teknologi informasi. Faktor tingkat kepercayaan ini erat kaitannya dengan persepsi risiko yang juga merupakan variabel eksternal dari teori TAM, karena seseorang tidak akan memercayai suatu hal apabila ia merasa resiko yang mungkin terjadi masih cukup besar.

Penelitian ini mampu menambah wawasan ilmu pengetahuan mengenai teori Technology Acceptance Model (TAM) serta pengaruh persepsi manfaat, persepsi kemudahan penggunaan, dan tingkat kepercayaan pada minat menggunakan uang elektronik.

Penelitian ini mampu memberikan berbagai pertimbangan kepada pihak perusahaan issuer uang elektronik agar mampu meningkatkan minat masyarakat untuk menggunakan uang elektronik dalam kaitannya dengan faktor-faktor diatas. Selain itu penelitian ini juga mampu memberikan suatu informasi untuk penelitian selanjutnya, guna untuk penyempurnaan penelitian mengenai hal sejenis.

\section{SIMPULAN}

Hasil penelitian ini membuktikan persepsi manfaat berpengaruh positif terhadap minat menggunakan uang elektronik. Hal ini berarti bahwa semakin besar persepsi manfaat akan meningkatkan minat menggunakan uang elektronik. 
Hasil penelitian ini membuktikan persepsi kemudahan penggunaan berpengaruh positif terhadap minat menggunakan uang elektronik. Hal ini berarti bahwa semakin besar persepsi kemudahan penggunaan akan meningkatkan minat menggunakan uang elektronik.

Hasil penelitian ini membuktikan kepercayaan berpengaruh positif terhadap minat menggunakan uang elektronik. Hal ini berarti bahwa semakin besar kepercayaan akan meningkatkan persepsi penggunaan uang elektronik.

Bagi pihak issuer uang elektronik agar semakin meningkatkan kualitas uang elektronik dari segi faktor-faktor yang menjadi fokus pada penelitian ini yang dapat meningkatkan minat masyarakat untuk menggunakan uang elektronik.

Bagai pihak yang ingin meneliti lebih lanjut agar memperluas jangkauan penelitian serta mangambil objek-objek lain dimasyarakat sehingga mampu mengidentifikasi faktor-faktor lain yang memengaruhi minat menggunakan uang elektronik, kerena dalam penelitian ini terdapat $42,8 \%$ faktor-faktor lain yang memengaruhi minat menggunakan uang elektronik. Selain itu disarankan untuk memfokuskan jenis uang elektronik yang ingin diteliti, misalnya uang elektronik yang berjenis digital purse, seperti Go-pay, Grab-pay, Dana, dan OVO.

\section{REFERENSI}

Adhinagari, A. H. (2018). Pengaruh Persepsi Manfaat, Persepsi Kemudahan, Kepercayaan dan Persepsi Resiko Terhadap Persepsi Penggunaan E-money. Skripsi. Yogyakarta:Universitas Islam Indonesia

Adiyanti, A. I. (2015). Pengaruh Pendapatan, Manfaat, Kemudahan Penggunaan, Daya Tarik Promosi, dan Kepercayaan Terhadap Minat Menggunakan Layanan E-Money (Studi Kasus : Mahasiswa Universitas Brawijaya). Jurnal Ilmiah Mahasiswa Fakultas Ekonomi dan Bisnis Universitas Brawijaya. 3 
(1)

Ajzen, I., \& Fishbein, M. (1980). Understanding Attitudes and Predicting Social Behavior. Englewood Cliffs, NJ: Prentice-Hall.

Ba, S., \& Pavlou, P. (2002). Evidence OF the Effect of Trust Building Technology in Electronic Markets: Price Premiums and Buyer Behavior. MIS Quarterly 26.

Chiu, J., \& Wong, T.-N. (2014). E-money: Effiency, Stability, and Optimal Policy. Bank Of Canada Working Paper.

Dalcher, I., \& Shine, J. (2003). Extending the New Technology Acceptance Model to Measure the End User Information Systems Satisfaction in a Mandatory Environment: A Bank's Treasury. Technology Analysis \& Strategic Management, 15(4), 441-455.

Davis, F. D., Bagozzi, R. P., \& Warshaw, P. R. (1989). User Acceptance of Computer Technology: A Comparison of Two Theoretical Models. Management Science, 35(8), 982-1003.

Dirk, H. F. (2017). How Tracking of Electronic Money might Improve Financial Market Crisis Intervention. Management, 12 (4), 301-316.

Gefen, D. (2002). Customer Loyalty in E-Commerce. Journal of the Association for Information Systems 3, 27-51.

Hidayati, S., Nuryanti, I., Firmansyah, A., Fadli, A., Darmawan, I. Y. (2006). Kajian Operasional E-money. Jakarta:Bank Indonesia.

Jogiyanto, H. M. (2007). Sistem Informasi Keperilakuan. Yogyakarta: Erlangga.

Listianti, U. Y. (2018). Pengaruh Kepercayaan, Persepsi Kemudahan dan Persepsi Manfaat Terhadap Minat Penggunaan E-money pada Mahasiswa FEB UMS. Jurnal. Surakarta: Universitas Muhammadiyah Surakarta.

Purwiati, E. (2013). Faktor-faktor yang Mempengaruhi Adopsi E-money. Tesis. Yogyakarta:Universitas Gadjah Mada.

Sanofata, D. (2014). Analisis Faktor-faktor Yang Mempengaruhi Intensi Penggunaan Electronic Money. Skripsi. Yogyakarta:Universitas Gadjah Mada.

Seng, L. C., \& Ping, N. S. (2016). The Influence of Product Innovation Toward Consumer Purchase Intention. Journal of Economics, Commerce, and Management IV(4), 773-782. 
Utami, S. S. (2017). Faktor-faktor Yang Memengaruhi Minat Penggunaan EMoney (Studi pada Mahasiswa STIE Ahmad Dahlan Jakarta). XIV(2).

Wanandi, H. C. (2014). Pengaruh Persepsi Kebermanfaatan, Persepsi Kemudahan Penggunaan Dan Computer Self Efficacy, Terhadap Penggunaan Online Banking Pada Mahasiswa S1 Fakultas Ekonomi Universitas Negeri Yogyakarta. Skripsi. Universitas Negeri Yogyakarta.

Wibowo, S. F. (2015). Pengaruh Persepsi Manfaat, Persepsi Kemudahan, Fitur Layanan, dan Kepercayan Terhadap Minat Mengguanakan E-money Card (Studi Pada Pengguna Jasa Commuterline Di Jakarta). Jurnal Riset Manajemen Sains Indonesia, 440-456.

Zulqarnain, S. (2017). Pengaruh Daya Tarik Promosi, Persepsi Kemudahan, dan Persepsi Kemanfaatan Terhadap Minat Menggunakan E-money. Skripsi. Yogyakarta:Universitas Islam Negeri Sunan Kalijaga. 